Pak. j. sci. ind. res. Ser. B: biol. sci. 2021 64B(2) 202-210

\title{
Review
}

\section{Green Synthesis of Magnetic Iron Oxide Nanoparticle for Antibacterial Activity: A Review}

\author{
Muhammad Isa khan, Aliza Zahoor, Tahir Iqbal, Abdul Majid and Mohsin Ijaz* \\ Department of Physics, Faculty of Sciences, University of Gujrat, Hafiz Hayat Campus, Gujrat 50700, Pakistan
}

(received February 26, 2019; revised June 21, 2019; accepted July 12, 2019)

\begin{abstract}
Recently, different researchers find nanoparticles as an auspicious alternative to antibacterial agents due to their antibacterial behaviour. This antibacterial behaviour contributes in many biomedical applications including; tissue engineering, drug and gene delivery and, imaging. Furthermore, iron oxide nanoparticle gains much importance due to their magnetic characteristics and wide range of application. Iron oxide nanoparticle (IONPs) have exhibits great potential against bacteria. During the past decade, various routes were developed to synthesize iron oxide nanoparticle with suitable size and composition. This article reviews the recent iron oxide nanoparticle obtained by green synthesis with a focus on their response to antibacterial activities. The iron nanoparticles synthesized by green synthesis method has accumulated a vital attention over the last couple of years due to their unique characteristic as it makes sure environmental friendly, nontoxic and safe reagents.
\end{abstract}

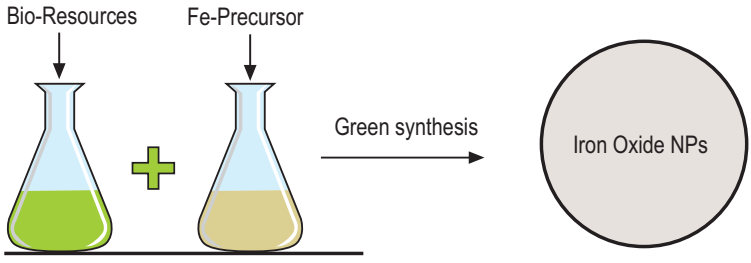

Keywords: iron oxide, antibacterial activity, nanoparticles, green synthesis

\section{Introduction}

In nanotechnology, matter is manipulated using numerous physical or chemical routes to yield materials at nanoscale with dimension 1-100 nanometers, that leads to precise properties useful in several applications because of their large surface area to volume ratio (Salata, 2004) and (Iqbal et al., 2019). Nanoparticles have extensive range of applications in the most advanced fields such as sensors (Rao and Paria, 2013), electronics (Shahwan et al., 2011), biomedical (Naik et al., 2002), photo-catalysis (Zhang et al., 2012), catalysts (Frey and Sun 2009) etc. The iron oxide nanoparticles founded to have distinctive magnetic properties and superior bio-compatibility. Furthermore, these nanoparticles made a lot of promises since last decade and made a remarkable contribution to improve the livelihood of mankind. Green synthesis of iron oxide nanoparticles is a bottom up methodology, where the

*Author for correspondence;

E-mail: isaiub@yahoo.com; mohsin@live.no reaction may be oxidation and reduction (Naik et al., 2002).

Bacteria is responsible for promoting infectious diseases in plants and other living organisms which are potentially life threating. This problem drove scientific society towards the improvement of synthetic antibacterial reagent. (Vimbela et al., 2017) Production cost of traditional antibacterial agents intensifying the burden on economy of the world but still these microbes are developing resistance against these antibacterial agents. So, continuous improvement in the traditional antibacterial agents is necessary (Zhou et al., 2012). In the last decades, the treatment involved in infections caused by bacteria has become more complicated due to the emergence of the resistance mechanisms which has resulted in life threatening infections. This led to the search of alternate materials which can be used as antibacterial agents (Allaker, 2010). As well as antibacterial agents are concerned, magnetic Iron Oxide nanoparticles (IONPs) have acknowledged for specifi- 
cation as they could be synthesized with highly potential active sites and with high surface area (Stoimenov et al., 2002).

Iron oxides have been lavishly appeared in earth crust that founded to be frequently used in a long range of bio-technological and biomedical applications. Nanoparticles synthesized from these iron oxides works for cancer treatment (thermal ablation, magnetic hyperthermia), diagnostic imaging (magnetic resonance imaging), scale-up bio separation procedures and biosensing-based applications (Wu et al., 2008) (Mohapatra and Anand, 2010). $\mathrm{Fe}_{3} \mathrm{O}_{4}$-NPs-based biomedical applications are of particular interest because of easy synthesis in laboratory, cost effectiveness, physical and chemical stability and also bio-compatible and safe to environmental (Ahmad et al., 2017; Irshad et al., 2017).

Basic structure of IONPs. The super paramagnetic iron oxide nanoparticles (SPIONs) like magnetite, maghemite or hematite have been widely used among other form of iron oxide nanoparticles, have broad application in biomedicine such as drug and gene delivery, repairing tissue, biological sensing, magnetic resonance imaging (MRI), hyperthermia and magneto-fection (Ansari et al., 2017). The word 'ferrihydrite' is frequently used to define both 2-line or 6-line ferrihydrite, have any 2 or 6 distinguishable wide reflections in the diffraction pattern. Different chemical formulations for ferrihydrite includes: $\mathrm{Fe}_{5}\left(\mathrm{O}_{4} \mathrm{H}_{3}\right)_{3}, \mathrm{Fe}_{5} \mathrm{HO}_{8}, 4 \mathrm{H}_{2} \mathrm{O}, \mathrm{Fe}_{2} \mathrm{O}_{3}, 2 \mathrm{FeOOH}, 2.6 \mathrm{H}_{2} \mathrm{O}$ and $5 \mathrm{Fe}_{2} \mathrm{O}_{3}, 9 \mathrm{H}_{2} \mathrm{O}$. The ferrihydrite have spherical morphology and occurs as nanocrystals (Eusterhues et al., 2008).

Magnetite $\left(\mathrm{Fe}_{3} \mathrm{O}_{4}\right)$ exists as black, ferro-magnetic mineral holding both $\mathrm{Fe}$ (II) and $\mathrm{Fe}$ (III) with cation deficient Fe(III) layer. The unit cell magnetite consists of 32 atoms of oxygen forming face centered cubic structure, with edge dimension of the unit cell of about $0.839 \mathrm{~nm}$ that leads to inverse spinal crystal structure. In this crystal structure, partial Fe(III) resides tetrahedral sites whereas the other part of $\mathrm{Fe}$ (III) ions and $\mathrm{Fe}$ (II) ions resides octahedral site. The trivalent Fe atoms reside octahedral and tetrahedral sites and have a Crystal Field Stabilization Energy $(\mathrm{CFSE})=0$ in both, while the divalent $\mathrm{Fe}$ atoms resides octahedral sites more favourably to take greater (CFSE). The magnetite has octahedron and rhombdecahedron crystal have specific surface area range $4-100 \mathrm{~m}^{2} / \mathrm{g}$ (Eusterhues et al., 2008) (Walsch and Dultz, 2010).

The hematite, $\alpha-\mathrm{Fe}_{2} \mathrm{O}_{3}$, have isostructure with corundum, $\alpha-\mathrm{Al}_{2} \mathrm{O}_{3}$. These structure has 3-D context assembled with trigonally slanted octahedra $\mathrm{FeO}_{6}$, connected to 13 neighbors by 6 vertices, 3 edges, and 1 face, with lattice parameters specified in the hexagonal cell: $\mathrm{a}=5.0346 \AA, \mathrm{c}=13.752 \AA$ with space group R3 c ( $\mathrm{N}^{\circ}$ 167 , rhombohedral symmetry). The structure of hematite is actually the stacking of sheets of octahedral, coordinated $\mathrm{Fe}^{+3}$ ions between two closed-packed layers of oxygen. The $\mathrm{Fe}-\mathrm{O}$ sheets joint together through strong covalent bonds. The iron has trivalent state so, each oxygen atom attached to two iron ions, and therefore, only two vacant oxygen octahedrons could be occupied, as a result of this arrangement structure becomes neutral having no charge lossor excess. The hematite has hexagonal crystal structure (Walsch and Dultz, 2010).

The 'lepidocrocite' $\gamma-\mathrm{FeO}(\mathrm{OH})$, have a crystal structure comprises of double sheets of Fe-octahedra, having hydroxyl groups placed on their outer sides. Actually, atoms of hydrogen inhibit the centers of inversion and have been positioned at an equal distance from the two oxygen atoms of the neighboring sheets. Consequently, forms a continuous chains of $\mathrm{O}-\mathrm{H}-\mathrm{O}-\mathrm{H}-\mathrm{O}$ with symmetric hydrogen bonds. Lepidocrocite have lathlike or tabular crystal structure (Eusterhues et al., 2008).

The structure of Goethite, $\alpha-\mathrm{FeO}(\mathrm{OH})$ have an orthorhombic symmetry with space group Pnma ( $\mathrm{N}^{\circ}$ 62). The crystal structure of goethite is built up by 3 D structure of $\mathrm{FeO}_{3}(\mathrm{OH})_{3}$ octahedral and each octahedron is connected to neighboring eight octahedral by 3 vertices and 4 edges. The $\mathrm{OFe}_{3} \mathrm{H}$ (bond) or $\mathrm{OFe}_{3} \mathrm{H}$ surrounds the oxygen atoms tetrahedrally. Goethite has acicular morphology (Eusterhues et al., 2008).

The synthesize technique of iron oxide have significant important because their unique properties arise due to reduced size of nanoparticle. The key issues of iron oxide nanoparticles include; uniformity in shape and, size of nanoparticle. There are numerous methods to synthesize of IONPs such as; sonochemical (Vijayakumar et al., 2000), sol-gel method (Bagheri

Table 1. Common structures of iron oxide nanoparticles (Mohapatra and Anand, 2010)

\begin{tabular}{lll}
\hline \hline Iron oxide & Morphology & Specific surface area \\
\hline Magnetite & $\begin{array}{l}\text { Octahedron and } \\
\text { rhombdecahedron }\end{array}$ & $4-100 \mathrm{~m}^{2} / \mathrm{g}$ \\
Hematite & Hexagonal & $10-90 \mathrm{~m}^{2} / \mathrm{g}$ \\
Iepidocrocite & Tabular & $15-260 \mathrm{~m}^{2} / \mathrm{g}$ \\
Goethite & Acicular & $8-200 \mathrm{~m}^{2} / \mathrm{g}$ \\
Ferrihydrite & Spherical & $100-700 \mathrm{~m}^{2} / \mathrm{g}$ \\
\hline \hline
\end{tabular}


et al., 2013), hydrothermal method (Giri et al., 2005), flow injection synthesis (Salazar-Alvarez et al., 2006), microemulsion process (Vidal-Vidal et al., 2006), radiolysis (Abedini et al., 2014), microwave method (Carenza et al., 2014), laser pyrolysis (Bomatí-Miguel, et al., 2008), aerosol pyrolysis (Tartaj et al., 2004) and many others (Li et al., 2019; Saqib et al., 2019). Synthesis of nanoparticles by chemical or physical routes may drop their reactivity because of accumulation of air exposure (Kim et al., 2008) and magnetism. (Wu et al., 2008). As these routes involves chemical precursors contaminated chemicals and, formation of unsafe by-products (Thakkar et al., 2010). The Green synthesis offers progression over physical and chemical routes because it is environmental friendly, easily scaled up for large scale synthesis and the method doesn't require the use of high pressure, cost effective, toxic chemicals and high temperature (Shankar et al., 2004).

During the last two decades, it founds challenging and active zone of research to synthesize the iron oxides nanoparticles for different applications. This process involves to carefully chose temperature, $\mathrm{pH}$, concentration of reactants, process of mixing, and also rate of oxidation (DoMINGO et al., 1994). The morphology of IONPs depends upon adsorption of impurities, aggregation, nucleation and, growth (Cornell and Schwertmann, 1996). Although, it is not always probable to get IONPs directly in required shape and size. So, it followed to transform iron oxide precursor additionally which is sensitive to results (Butter et al., 2005; Baker et al., 2000). The following sections briefly review the iron oxide nanoparticle synthesized by green synthesis with the focuses on their antibacterial activity.

Green synthesis. For the synthesis of micro and nano scaled inorganic materials, nature has developed many routes, which contributes advancement towards novel and unexplored field of research centered on the biosynthesis of nano-scale materials $(1-100 \mathrm{~nm})$. Nanoparticles synthesized by "Green synthesis" makes the use of non-toxic, environmental friendly and safe reagents. (Afsheen et al., 2018) These nanoparticles have diverse natures, with suitable dimension and greater stability as they are synthesized through one-step procedure and uses less energy makes it eco-friendly (Kharissova et al., 2013; Luechinger et al., 2009). In general, green nanotechnology uses biological routes such as plants, microorganisms and viruses with the help of different technological tools to synthesize nanoparticles. Nanoparticles synthesized through green synthesis found to be superior to those synthesize by other physical or chemical routs due to numerous aspects. Since, green synthesis consumes less energy, reduce the use of costly chemicals, and generate environmentally benign products and by products (Singh et al., 2011; Narayanan and Sakthivel, 2011).

To developed metallic nanoparticles using plants employs that dehydrated the metallic salt and biomass of the plants, as precursor and bio reducing agent respectively. Magnetic NPs synthesized biologically exploits a bottom-up approach in which synthesize nanoparticles is made with through the stabilizing and reducing reagents. The nanoparticles synthesis by using a biological rout is followed by three steps: the excellence of solvent medium uses, the excellence of a nontoxic material as a topping agent, and the excellence of an environmental friendly and is to stabilize the synthesized nanoparticles (Shinde et al., 2012; Krutyakov et al., 2008).

Synthesis of IONPs using plant extract. Generation of iron oxide nanoparticles with green synthesis route by using different parts of plant like seed, root, stem and leaf is the modest, reproducible and the most cost effective methodology (Kalaiarasi et al., 2010). The iron oxide nanoparticles produced by plants proved to be the most stable and best applicants' where stable and large-scale synthesis of these magnetic nanoparticles is required. Because plants have natural configuration of various organic reducing components, that are simply disseminate towards the synthesis of magnetic NPs (Mukunthan and Balaji, 2012; Iravani, 2011). Consequently, the effectiveness of phytochemicals based on plant in whole synthesis and construction of NPs develops cooperation between sciences and nanotechnology which gives green approach to nanotechnology, which can be raised to as green nanotechnology without environmental pollution. Hence this concept leads to eco-friendly solution to problems (Shukla et al., 2012). All the plants parts are used to synthesize iron oxide nanoparticles like, leafs, seeds, bran and fruit extract.

The iron oxide nanoparticles synthesized by green synthesis route by means of various plant extracts had been reported by several researchers. Plant-mediated metallic IONPs are rapidly processed and low cost, is an alternative to chemically synthesis practices. (Iqbal et al., 2016) The iron oxide NPs synthesized by extract of Tridax procumbens leaf with reduction of ferric chloride $\left(\mathrm{FeCl}_{3}\right)$. The extract of Tridax $p$. contains carbohydrate compounds that are soluble in water. The carbohydrates contain aldehyde group that may help to reduce $\mathrm{Fe}^{+3}$ of ferric chloride to $\mathrm{Fe}_{3} \mathrm{O}_{4}$ nanoparticles (Küünal et al., 2018; Saif et al., 2016). 
Iron oxide NPs could be easily synthesizing by using Camellia sinensis leaves (Green Tea). Synthesis of IONPs can be prepared by adding Camellia sinensis leaves extract and $0.01 \mathrm{M}$ Ferric Chloride in a clean sterilized flask with 1:1 ratio. The polyphenols consist of flavanoids and Catechins, present in Camellia sinensis (Green tea) reduce the salt precursors to nanoparticles. The Epigallocatechin Gallate (EGCG) which is an active catechin has standard potential of $0.58 \mathrm{~V}$ that takes part in reduction process, which reduces the $\mathrm{Fe}^{+3}$ to $\mathrm{FeO}$ and has standard potential equals to $-0.036 \mathrm{~V}$. Polyphenols in Green tea leaves extract act as capping agents and have the properties of reducing ferric cations which shows that the IONPs to synthesized from Camellia sinensis (Green tee) leaves extract has an antibacterial property against Escherichia coli (Gottimukkala et al., 2017).

Iron oxide nanoparticles synthesized by the addition of $0.01 \mathrm{M} \mathrm{FeCl}_{3} \cdot 6 \mathrm{H}_{2} \mathrm{O}$ solution to the Lagenaria siceraria leaves extract in the 1:1 ratio. The iron oxide nanoparticles were instantaneously developed due to reduction process because LS leaves have the best reduction capability against ferric chloride. FT-IR results shows the stretching vibrations, $-\mathrm{OH}$ bond and $\mathrm{C}=\mathrm{O}$ bond which shows the aqueous phase and the phytochemicals present in the plant extract and amino acids which stabilize and also act as a covering agents respectively. The zeta potential of $\mathrm{Fe}_{3} \mathrm{O}_{4}$-NPs was $-52 \mathrm{meV}$ proves the synthesized NPs are highly stable because of the strong (-ve) surface charge density (Kanagasubbulakshmi and Kadirvelu, 2017).

Iron oxide nanoparticles easily synthesize by Sageretia thea (Osbeck), by using iron sulfate hepta hydrate as a precursor. The XRD, HR-SEM/TEM and SEAD results shows that iron oxide NPs are tetragonal crystalline in shape with particle size about $30 \mathrm{~nm}$. The fourier transform infrared spectroscopy (FTIR) results shows $\mathrm{Fe}-\mathrm{O}$ vibration mode and broad $-\mathrm{OH}$ stretching which attribute to the presence of phenolic compounds. These IR absorptions attribute the phytochemical compounds that further used in capping, reduction and, moreover to stabilize the IONPs (Khalil et al., 2017).

The iron oxide nanoparticles by Azadinia indica leaf extract can be synthesized by mixing $A$. Indica leaves extract with $0.1 \mathrm{M}$ metal salt $\mathrm{FeSO}_{4}$ in $1: 5$ ratios. The characterization results exhibits that, the $A$. Indica yields iron oxide nanoparticles spherical in shape having size ranges from $98-200 \mathrm{~nm}$. FTIR results are evident to concentration of polyphenols and presence of Fe NPs. The polyphenols compounds are acknowledged to have antibacterial behaviour (Devatha et al., 2018; Romero et al., 2007).

The Punica granatum plant used to synthesize IONPs by using Punica $g$. peel extract and ferric chloride hexahydrate $\left(\mathrm{FeCl}_{3} \cdot 6 \mathrm{H}_{2} \mathrm{O}\right)$ as a precursor. The XDR results confirm that the nanoparticles are purely crystalline in shape. The FT-IR revealed the existence of phytochemicals composites in Punica granatum peel extract. These phytochemicals compound acts as reducing and stabilizing agents. These nanoparticle has inhibition on Pseudomonas aeruginosa strain (Irshad et al., 2017).

The iron oxide nanoparticles were obtained with Lawsonia inermis (Henna) and Gardenia jasminoides plant extract. $\mathrm{FeSO}_{4}$ (filtrate) acts as reducing, capping, and stabilizing agent in the synthesis of iron oxide nanoparticles (Makarov et al., 2014). The XRD, TEM, SEM- EDX results reveals that the IONPs have size $21 \mathrm{~nm}$ and $32 \mathrm{~nm}$ with hexagonal are rock like structure for iron oxide nanoparticle obtained from henna and Gardenia leaves extract respectively. These nanoparticles show a strong effect against the habitation of Salmonella enterica, Escherichia coli, Staphylococcus aureu and Proteus mirabilis bacteria (El-Hag et al., 2007; Naseem and Farrukh, 2015).

The IONPs produced by using Moringa oleifera leaf extract and seed extract. The solution is prepared by mixing different proportions of Moringa oleifera plant extracts with iron chloride solution that act as a precursor. These nanoparticles are characterized by using different characterization techniques like; dynamic light scattering, UV-Visible spectroscopy, XRD, FTIR and TEM. Results revealed that these iron oxide nanoparticles have great potential against bacterial habitation. The maximum inhibition zone against Escherichia coli bacteria observed by iron oxide nanoparticle synthesized by Moringa oleifera seed extract and Moringa oleifera leaf extract is $6 \mathrm{~nm}$ and $5 \mathrm{~nm}$ respectively (Katata-Seru et al., 2018).

The iron oxide nanoparticle was synthesize using Glycosmis mauritiana leaves and $\mathrm{FeCl}_{3} \cdot 6 \mathrm{H}_{2} \mathrm{O}$ and $\mathrm{FeCl}_{2} \cdot 4 \mathrm{H}_{2} \mathrm{O}$. The characterization of these nanoparticle shows that the iron oxide nanoparticles crystalline in nature having average particle size about $100 \mathrm{~nm}$ and cubic in shape. Also, reported by other authors who found iron oxide nanoparticle $100 \mathrm{~nm}$ in size when synthesize with Lagenaria siceraria (Kanagasubbulakshmi and Kadirvelu, 2017). The synthesized iron oxide nanoparticles show great inhibition of bacterial strain. By increasing the density of iron oxide nanoparticles, the bacterial strain growth was inhibited gradually 
Table 2. Green synthesis of various plant and their antibacterial activity, size and shape

\begin{tabular}{|c|c|c|c|c|c|c|}
\hline Precursor & Plants & $\begin{array}{l}\text { Antibacterial } \\
\text { activity against }\end{array}$ & $\begin{array}{l}\text { NPs size } \\
\text { and shape }\end{array}$ & $\begin{array}{l}\text { Part of } \\
\text { plant used }\end{array}$ & $\begin{array}{l}\text { Characterization } \\
\text { technique }\end{array}$ & Reference \\
\hline $\begin{array}{l}\text { Ferrous sulph- } \\
\text { ate heptahydrate } \\
\mathrm{FeSO}_{4} \cdot 7 \mathrm{H}_{2} \mathrm{O}\end{array}$ & $\begin{array}{l}\text { Azadirachita } \\
\text { indica }\end{array}$ & $\begin{array}{l}\text { S. Aureus, E. Coli, } \\
\text { and P. Aeruginosa }\end{array}$ & $\begin{array}{l}98-200 \mathrm{~nm} \\
\text { spherical shape }\end{array}$ & Leaf & $\begin{array}{l}\text { SEM, XDS, } \\
\text { FTIS }\end{array}$ & $\begin{array}{l}\text { (Devatha } \\
\text { et al., 2018) }\end{array}$ \\
\hline Ferric Chloride & $\begin{array}{l}\text { Camellia sinensis } \\
\text { leaves (Green Tea) }\end{array}$ & Escherichia coli & $128 \mathrm{~nm}$ & Leaf & SEM, FTIS & $\begin{array}{l}\text { (Gottimukkala } \\
\text { et al., 2017) }\end{array}$ \\
\hline $\begin{array}{l}\text { Iron sulfate } \\
\text { heptahydrate }\end{array}$ & $\begin{array}{l}\text { Sageretia thea } \\
\text { (Osbeck.) } \\
\text { Escherichia coli, }\end{array}$ & $\begin{array}{l}\text { Staphylococcus } \\
\text { epidermidis, crystalline } \\
\text { P. aeruginosa } \\
\text { Bacillus subtilis and } \\
\text { Klebsiella pneumoniae }\end{array}$ & $\begin{array}{l}30 \mathrm{~nm}, \\
\text { Tetragonal }\end{array}$ & Leaf & $\begin{array}{l}\text { XRD, FTIR, RS, } \\
\text { EDS, HR- } \\
\text { SEM/TEM } \\
\text { and SAED }\end{array}$ & $\begin{array}{l}\text { (Khalil et al., } \\
\text { 2017) }\end{array}$ \\
\hline $\begin{array}{l}\text { Ferrous sulphate } \\
\left(\mathrm{FeSO}_{4}\right)\end{array}$ & Ocimum sanctum & Escherichia coli, & $\begin{array}{l}20 \mathrm{~nm} \text { Irregular } \\
\text { shape }\end{array}$ & Leaf & $\begin{array}{l}\text { FTIR, XRD, XEM, } \\
\text { SEM,TEM }\end{array}$ & $\begin{array}{l}\text { (Ahmad et al., 2017; } \\
\text { Balamurughan } \\
\text { et al., 2014) }\end{array}$ \\
\hline $\mathrm{FeSO}_{4}$ & $\begin{array}{l}\text { Lawsonia inermis } \\
\text { (Henna) }\end{array}$ & $\begin{array}{l}\text { Escherichia coli, } \\
\text { Salmonella enterica, } \\
\text { Proteus mirabilis, and } \\
\text { Staphylococcus aureus }\end{array}$ & $\begin{array}{l}21 \mathrm{~nm} \text { and } \\
\text { hexagonal in } \\
\text { shape }\end{array}$ & Leaf & $\begin{array}{l}\text { TEM, SEM, FTIR, } \\
\text { XRD, TGA, AFM }\end{array}$ & $\begin{array}{l}\text { (Naseem and } \\
\text { Farrukh, 2015; } \\
\text { El-Hag et al., } \\
\text { 2007) }\end{array}$ \\
\hline $\begin{array}{l}\text { Ferric chloride } \\
\text { hexahydrate } \\
\left(\mathrm{FeCl}_{3} \cdot 6 \mathrm{H}_{2} \mathrm{O}\right)\end{array}$ & Punica granatum & $\begin{array}{l}\text { Pseudomonas } \\
\text { aeruginosa }\end{array}$ & ------------- & $\begin{array}{l}\text { Peel } \\
\text { extract }\end{array}$ & $\begin{array}{l}\text { UV-visible } \\
\text { spectrophotometer, } \\
\text { SEM, EDX, XRD } \\
\text { and, FT-IR }\end{array}$ & (Irshad et al., 2017) \\
\hline $\begin{array}{l}\text { Ferric chloride } \\
\text { hexahydrate } \\
\left(\mathrm{FeCl}_{3} \bullet\right. \\
\left.6 \mathrm{H}_{2} \mathrm{O}, 98 \%\right)\end{array}$ & $\begin{array}{l}\text { Lagenaria } \\
\text { siceraria }\end{array}$ & Escherchia coli, & $\begin{array}{l}30-100 \mathrm{~nm} \\
\text { Cubic } \\
\text { shaped }\end{array}$ & Leaf & $\begin{array}{l}\text { UV-visible } \\
\text { spectrophotometer, } \\
\text { SEM, EDX, XRD, } \\
\text { Zeta sizer, and FT-IR }\end{array}$ & $\begin{array}{l}\text { (Kanagasubbulakshmi } \\
\text { and Kadirvelu, 2017) }\end{array}$ \\
\hline Iron chloride & Moringa oleifera & Escherichia coli & --------------- & $\begin{array}{l}\text { Leaf } \\
\text { and } \\
\text { seed }\end{array}$ & $\begin{array}{l}\text { UV-visible } \\
\text { spectrophotometer, } \\
\text { SEM, XRD, and } \\
\text { FT-IR }\end{array}$ & $\begin{array}{l}\text { (Katata-Seru et al., } \\
\text { 2018) }\end{array}$ \\
\hline $\mathrm{FeSO}_{4}$ & $\begin{array}{l}\text { Gardenia } \\
\text { jasminoides }\end{array}$ & $\begin{array}{l}\text { Escherichia coli, } \\
\text { Salmonella enterica, } \\
\text { Proteus mirabilis, and } \\
\text { Staphylococcus aureus }\end{array}$ & $\begin{array}{l}32 \mathrm{~nm} \text { and rock } \\
\text { like structure }\end{array}$ & Leaf & $\begin{array}{l}\text { TEM, SEM, FTIR, } \\
\text { XRD, } \\
\text { TGA, AFM }\end{array}$ & $\begin{array}{l}\text { (Naseem and } \\
\text { Farrukh, 2015) }\end{array}$ \\
\hline $\begin{array}{l}\text { Ferric chloride } \\
\text { solution }\end{array}$ & Tridax procumbens & --------- & $\begin{array}{l}80-100 \mathrm{~nm} \\
\text { irregular } \\
\text { sphere shape }\end{array}$ & $\begin{array}{l}\text { Leaf } \\
\text { crystalline }\end{array}$ & $\begin{array}{l}\text { UV-visible } \\
\text { spectrophotometer, } \\
\text { TEM, SEM, FTIR, } \\
\text { XRD }\end{array}$ & (Suganya et al., 2016) \\
\hline $\begin{array}{l}\mathrm{FeCl}_{3} \cdot 6 \mathrm{H}_{2} \mathrm{O} \text { and } \\
\mathrm{FeCl}_{2} \cdot 4 \mathrm{H}_{2} \mathrm{O}\end{array}$ & $\begin{array}{l}\text { Glycos } \\
\text { mismauritiana }\end{array}$ & $\begin{array}{l}\text { B. cereus, B. subtilis } \\
\text { E. faecalis, E. coli } \\
\text { K. pneumoia, M. luteus } \\
\text { P. mirabilis, } P \text {. vulgari } \\
\text { P. fluorescence, } \\
\text { S. aureus, } \text { V.fluvialis }\end{array}$ & $\begin{array}{l}100 \mathrm{~nm} \text { Cubic } \\
\text { shape }\end{array}$ & Leaf & $\begin{array}{l}\text { UV-visible (Amutha } \\
\text { and Sridhar, 2018) } \\
\text { spectrophotometer, } \\
\text { DSL, SEM, FTIR, } \\
\text { XRD }\end{array}$ & \\
\hline Ferric chloride & $\begin{array}{l}\text { Sargass } \\
\text { ummuticum }\end{array}$ & ------------ & $18 \pm 4 \mathrm{~nm}$ & $\begin{array}{l}\text { Plant } \\
\text { Cubic } \\
\text { shape }\end{array}$ & $\begin{array}{l}\text { UV-visible } \\
\text { spectrophotometer, } \\
\text { TEM, SEM, FTIR, } \\
\text { XRD,EDXRF, } \\
\text { VSM, FESEM }\end{array}$ & $\begin{array}{l}\text { (Mahdavi, Namvar, } \\
\text { Ahmad, } \\
\text { Mohamad, 2013) }\end{array}$ \\
\hline Iron chlorides & Passiflora foetida & $\begin{array}{l}\text { S. aureus, } \\
\text { K. pneumonia }\end{array}$ & $\begin{array}{l}20 \mathrm{~nm} \text { Spherical } \\
\text { shape } E \text {. coli, and } \\
\text { P. aeruginosa. }\end{array}$ & Leaf & $\begin{array}{l}\text { UV-visible } \\
\text { spectrophotometer, } \\
\text { SEM, FTIR, XRD }\end{array}$ & $\begin{array}{l}\text { (Suganya et al., } \\
\text { 2016) }\end{array}$ \\
\hline
\end{tabular}


(Amutha and Sridhar, 2018). The iron oxide nanoparticle shows significant antibacterial behavior against Escherichia coli, Klebsiella pneumonia, Staphylococcus aureus and, P. aeruginosa. When synthesized by Passiflora foetida and using iron chloride as a precursor (Suganya et al., 2016).

Simplest and well established method probably yields better magnetic iron oxide nanoparticle and green route no doubt is the simplest, cheap and ecofriendly route. Although, the magnetic iron oxide nanoparticle synthesized from green synthesis method are most stable and size of these iron oxide nanoparticle is compare to other traditional methods. For instance, the iron oxide nanoparticles synthesized by co-precipitation method found to be mostly Spherical magnetite with size range from 30-100 nm (Tartaj et al., 2005; Chastellain et al., 2004; Tartaj et al., 2003; Jolivet et al., 2000). That is comparable to green synthesis method but these nanoparticles require an extra coating for stability (Xu et al., 2006; Lin et al., 2005). The iron oxide nanoparticles yield by micro-emlusion method have size $(10 \mathrm{~nm})$ (Tartaj et al., 2003) comparable to those synthesize by Sargassum muticum plant (Mahdavi et al., 2013). But the main demerit of these nanoparticles is that, they have difficult scale-up process and residual surfactants have adverse effects on the properties of the nanoparticles (Tartaj et al., 2003; Pileni, 1993). The iron oxide nanoparticles synthesized by Spray and laser pyrolysis have size range 5-60 $\mathrm{nm}$ that is comparable to nanoparticles synthesized by green synthesis but equipment used in this method are highly expensive than price range of equipment used in green synthesis also have low yield percentage (Hasany et al., 2012).

Mechanism of action of IONPs against bacteria. The antibacterial behaviour of iron oxide nanoparticles for the bacterial cell is followed through the fabrication of intracellular "Reactive Oxygen Species" (ROS). The exited electron of iron oxide nanoparticles promotes the production ROSs which could be hydrogen peroxide $\left(\mathrm{H}_{2} \mathrm{O}_{2}\right)$, superoxide free radical $\left(\mathrm{O}_{2}\right)$ and hydroxyl free radical $(\mathrm{OH}$.) in the bacterial cell. These reactive oxygen species control the stimulation of the oxidative stress that tends to injur the cellular compounds such as; DNA, protein, cell membrane and other vital enzymes. Hence, the results obtained suggest that iron oxide nanoparticle synthesize by green synthesis include the interaction with the surface of bacterial cell and promote the production of intracellular reactive oxygen species results in the leakage of cytoplasmic constituents. Figure 1

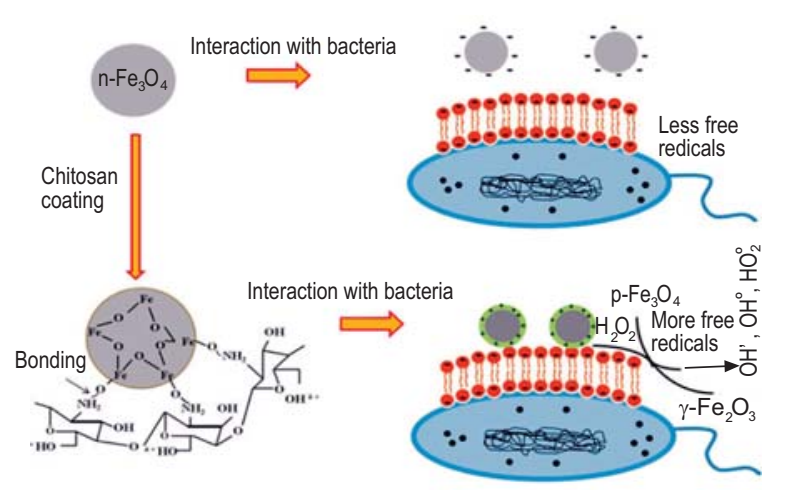

Fig. 1. Mechanism of action of IONPs against bacteria (Arakha et al., 2015).

shows the possible mechanism of action of IONPs for anti-bacterial activity.

\section{Conclusion}

This review focused the generation of iron oxide nanoparticles through green synthesis route and also their potential against antibacterial activity. This effort has been made to spot the different green mediators to synthesis IONPs from plant extract and their reaction trails. Review of the latest research work confirms that numerous plant resources are evolves for the superficial synthesis of iron oxide nanoparticles, that have great potential for antibacterial activity. Therefore, plant resources appeared to be more reasonable as mediators to generate of IONPs because it has eco-friendly individualities and low cost value, could be used as an alternate where large-scale production of nanoparticles is required.

Conflict of Interest. The authors declare no conflict of interest.

\section{References}

Frey, N., Sun, M. 2009. Shouheng Materials, "Magnetic Nanoparticle for Information Storage Applications," no: Richter, pp. 33-68, Gole, A.C., Dash, V., Ramachandran, S.R.

Abedini, A., Daud, A.R., Hamid, M.A.A., Othman, N.K. 2014. Radiolytic formation of $\mathrm{Fe}_{3} \mathrm{O}_{4}$ nanoparticles: influence of radiation dose on structure and magnetic properties. PloS One, 9: e90055.

Afsheen, S., Tahir, M.B., Iqbal, T., Liaqat, A., Abrar, M. 2018. Green synthesis and characterization of novel iron particles by using different extracts. Journal of Alloys and Compounds, 732: 935-944.

Ahmad, T., Phul, R., Khatoon, N., Sardar, M. 2017. 
Antibacterial efficacy of Ocimum sanctum leaf extract-treated iron oxide nanoparticles. New Journal of Chemistry, 41: 2055-2061.

Allaker, R. 2010. The use of nanoparticles to control oral biofilm formation. Journal of Dental Research, 89: $1175-1186$.

Amutha, S., Sridhar, S. 2018. Green synthesis of magnetic iron oxide nanoparticle using leaves of Glycosmis mauritiana and their antibacterial activity against human pathogens. Journal of Innouopions in Pharmaceutical and Biological Science (JLPBS), 5: 22-26. ISSN: 2349-2759.

Ansari, M.O., Ahmad, M., Parveen, N., Ahmad, S., Jameel, S., Shadab, G. 2017. Iron oxide nanoparticles-synthesis, surface modification, applications and toxicity: a review. Materials Focus, 6: 269279.

Arakha, M., Pal, S., Samantarrai, D., Panigrahi, T. K., Mallick, B.C., Pramanik, K., Jha, S. 2015. Antimicrobial activity of iron oxide nanoparticle upon modulation of nanoparticle-bacteria interface. Scientific Reports, 5: 14813.

Bagheri, S., Chandrappa, K., Hamid, S.B.A. 2013. Generation of hematite nanoparticles via sol-gel method. Research Journal of Chemical Sciences, 3: 62-68. ISSN 2231-606X.

Baker, A.S., Brown, A.S., Edwards, M.A., Hargreaves, J.S., Kiely, C.J., Meagher, A., Pankhurst, Q.A. 2000. A structural study of haematite samples prepared from sulfated goethite precursors: the generation of axial Mesoporous voids. Journal of Materials Chemistry, 10: 761-766.

Balamurughan, M., Mohanraj, S., Kodhaiyolii, S., Pugalenthi, V. 2014. Ocimum sanctum leaf extract mediated green synthesis of iron oxide nanoparticles: spectroscopic and microscopic studies. Journal of Chemical and Pharmaceutical Science, 4: 201-204.

Bomatí-Miguel, O., Mazeina, L., Navrotsky, A., Veintemillas-Verdaguer, S. 2008. Calorimetric study of maghemite nanoparticles synthesized by laserinduced pyrolysis. Chemistry of Materials, 20: 591-598.

Butter, K., Kassapidou, K., Vroege, G., Philipse, A. 2005. Preparation and properties of colloidal iron dispersions. Journal of Colloid and Interface Science, 287: 485-495.

Carenza, E., Barceló, V., Morancho, A., Montaner, J., Rosell, A., Roig, A. 2014. Rapid synthesis of waterdispersible superparamagnetic iron oxide nanoparticles by a microwave-assisted route for safe labeling of endothelial progenitor cells. Acta
Biomaterialia, 10: 3775-3785.

Chastellain, M., Petri, A., Hofmann, H. 2004. Particle size investigations of a multistep synthesis of PVA coated superparamagnetic nanoparticles. Journal of Colloid and Interface Science, 278: 353-360.

Cornell, R., Schwertmann, U. 1996. The Iron Oxides: Structure, Properties, Reactions, Occurrence and Uses, $2^{\text {nd }}$ Completely Revised and Extended Edition (E-Book), pp. 703, VCH Verlagsgesellshaft GMBH Weinheim, Germany.

Devatha, C., Jagadeesh, K., Patil, M. 2018. Effect of green synthesized iron nanoparticles by Azardirachta indica in different proportions on antibacterial activity. Environmental Nanotechnology, Monitoring and Management, 9: 85-94.

DoMINGO, C., Rodri' guez-Clemente, R., Blesa, M. 1994. Morphological properties of $\alpha-\mathrm{FeOOH}, \gamma-$ $\mathrm{FeOOH}$ and $\mathrm{Fe}_{3} \mathrm{O}_{4}$ obtained by oxidation of aqueous Fe (II) solutions. Journal of Colloid and Interface Science, 165: 244-252.

El-Hag, A., Al-Jabri, A., Habbal, O. 2007. Antimicrobial properties of Lawsonia inermis (henna): a review. Australian Journal of Medical Herbalism, 19: 114.

Eusterhues, K., Wagner, F.E., Ha"usler, W., Hanzlik, M., Knicker, H., Totsche, K.U., Schwertmann, U. 2008. Characterization of ferrihydrite-soil organic matter coprecipitates by X-ray diffraction and Mossbauer spectroscopy. Environmental Science and Technology, 42: 7891-7897.

Giri, S., Samanta, S., Maji, S., Ganguli, S., Bhaumik, A. 2005. Magnetic properties of $\alpha-\mathrm{Fe}_{2} \mathrm{O}_{3}$ nanoparticle synthesized by a new hydrothermal method. Journal of Magnetism and Magnetic Materials, 285: 296-302.

Gottimukkala, K.S.V., Silamkoti, A., Vedula, J.M. 2017. Antibacterial activity of iron nanoparticles synthesized from green tea leaves extract. Journal of Nanomedicine and Biotherapeutic Discovery, 7: 1.

Hasany, S., Ahmed, I., Rajan, J., Rehman, A. 2012. Systematic review of the preparation techniques of iron oxide magnetic nanoparticles. Nanosciences and Nanotechnology, 2: 148-158.

Iqbal, T., Ali, F., Khalid, N., Tahir, M.B., Ijaz, M. 2019. Facile synthesis and antimicrobial activity of CdS$\mathrm{Ag}_{2} \mathrm{~S}$ nanocomposites. Bioorganic Chemistry, 103064.

Iqbal, T., Hassan, A., Ghazal, S. 2016. Synthesis of iron oxide, cobalt oxide and silver nanoparticles by different techniques: a review. International Journal of Scientific Engineering Research (IJSER), 7: 1178-1221. 
Iravani, S. 2011. Green synthesis of metal nanoparticles using plants. Green Chemistry, 13: 2638-2650.

Irshad, R., Tahir, K., Li, B., Ahmad, A., Siddiqui, A.R., Nazir, S. 2017. Antibacterial activity of biochemically capped iron oxide nanoparticles: A view towards green chemistry. Journal of Photochemistry and Photobiology B: Biology, 170: 241-246.

Jolivet, J.-P., Henry, M., Livage, J. 2000. Metal Oxide Chemistry and Synthesis: from Solution to Solid State: Wiley-Blackwell, USA.

Kalaiarasi, R., Jayallakshmi, N., Venkatachalam, P. 2010. Phytosynthesis of nanoparticles and its applications. Plant Cell Biotechnology and Molecular Biology, 11: 1-16.

Kanagasubbulakshmi, S., Kadirvelu, K. 2017. Green synthesis of iron oxide nanoparticles using Lagenaria siceraria and evaluation of its antimicrobial activity. Defence Life Science Journal, 2: $422-427$.

Katata-Seru, L., Moremedi, T., Aremu, O.S., Bahadur, I. 2018. Green synthesis of iron nanoparticles using Moringa oleifera extracts and their applications: Removal of nitrate from water and antibacterial activity against Escherichia coli. Journal of Molecular Liquids, 256: 296-304.

Khalil, A.T., Ovais, M., Ullah, I., Ali, M., Shinwari, Z.K., Maaza, M. 2017. Biosynthesis of iron oxide $\left(\mathrm{Fe}_{2} \mathrm{O}_{3}\right)$ nanoparticles via aqueous extracts of Sageretia thea (Osbeck.) and their pharmacognostic properties. Green Chemistry Letters and Reviews, 10: 186-201.

Kharissova, O.V., Dias, H.R., Kharisov, B.I., Pérez, B.O., Pérez, V.M.J. 2013. The greener synthesis of nanoparticles. Trends in Biotechnology, 31: 240248.

Kim, J.-H., Tratnyek, P.G., Chang, Y.-S. 2008. Rapid dechlorination of polychlorinated dibenzo-p-dioxins by bimetallic and nanosized zerovalent iron. Environmental Science \& Technology, 42: 41064112.

Krutyakov, Y.A., Kudrinskiy, A.A., Olenin, A.Y., Lisichkin, G.V. 2008. Synthesis and properties of silver nanoparticles: advances and prospects. Russian Chemical Reviews, 77: 233.

Küünal, S., Rauwel, P., Rauwel, E. 2018. Plant Extract Mediated Synthesis of Nanoparticles Emerging Applications of Nanoparticles and Architecture Nanostructures $1^{\text {st }}$ Edition (E-book), pp. 668, Elsevier.

Li, J., Nickel, R., Wu, J., Lin, F., van Lierop, J., Liu, S. 2019. A new tool to attack biofilms: Driving magnetic iron-oxide nanoparticles to disrupt the matrix. Nanoscale, 14: https: //doi.org 110.1039/ DIN RO1005K

Lin, C.-L., Lee, C.-F., Chiu, W.-Y. 2005. Preparation and properties of poly (acrylic acid) oligomer stabilized super paramagnetic ferro fluid. Journal of Colloid and Interface Science, 291: 411-420.

Luechinger, N.A., Grass, R.N., Athanassiou, E.K., Stark, W.J. 2009. Bottom-up fabrication of metal/metal nanocomposites from nanoparticles of immiscible metals. Chemistry of Materials, 22: 155-160.

Mahdavi, M., Namvar, F., Ahmad, M., Mohamad, R. 2013. Green biosynthesis and characterization of magnetic iron oxide $\left(\mathrm{Fe}_{3} \mathrm{O}_{4}\right)$ nanoparticles using seaweed (Sargassum muticum) aqueous extract. Molecules, 18: 5954-5964.

Makarov, V., Love, A., Sinitsyna, O., Makarova, S., Yaminsky, I., Taliansky, M., Kalinina, N. 2014. "Green" nanotechnologies: synthesis of metal nanoparticles using plants. Acta Naturae (English Version), 6: 35-44.

Mohapatra, M., Anand, S. 2010. Synthesis and applications of nano-structured iron oxides/ hydroxides-a review. International Journal of Engineering, Science and Technology, 2: 127-146.

Mukunthan, K., Balaji, S. 2012. Silver nanoparticles shoot up from the root of Daucus carrota (L.). International Journal of Green Nanotechnology, 4: 54-61.

Naik, R.R., Stringer, S.J., Agarwal, G., Jones, S.E., Stone, M.O. 2002. Biomimetic synthesis and patterning of silver nanoparticles. Nature Materials, 1: 169 .

Narayanan, K.B., Sakthivel, N. 2011. Green synthesis of biogenic metal nanoparticles by terrestrial and aquatic phototrophic and heterotrophic eukaryotes and biocompatible agents. Advances in Colloid and Interface Science, 169: 59-79.

Naseem, T., Farrukh, M.A. 2015. Antibacterial activity of green synthesis of iron nanoparticles using Lawsonia inermis and Gardenia jasminoides leaves extract. Journal of Chemistry, 2015: http://doi.org/ 10.1155/2015/912342

Pileni, M. 1993. Reverse micelles as microreactors. The Journal of Physical Chemistry, 97: 6961-6973.

Rao, K.J., Paria, S. 2013. Green synthesis of silver nanoparticles from aqueous Aegle marmelos leaf extract. Materials Research Bulletin, 48: 628-634.

Romero, C., Medina, E., Vargas, J., Brenes, M., De Castro, A. 2007. In vitro activity of olive oil polyphenols against Helicobacter pylori. Journal of Agricultural and Food Chemistry, 55: 680-686.

Saif, S., Tahir, A., Chen, Y. 2016. Green synthesis of 
iron nanoparticles and their environmental applications and implications. Nanomaterials, 6: 209.

Salata, O.V. 2004. Applications of nanoparticles in biology and medicine. Journal of Nanobiotechnology, 2: 3 .

Salazar-Alvarez, G., Muhammed, M., Zagorodni, A.A. 2006. Novel flow injection synthesis of iron oxide nanoparticles with narrow size distribution. Chemical Engineering Science, 61: 4625-4633.

Saqib, S., Munis, M.F.H., Zaman, W., Ullah, F., Shah, S.N., Ayaz, A., Bahadur, S. 2019. Synthesis, characterization and use of iron oxide nano particles for antibacterial activity. Microscopy Research and Technique, 82: 415-420.

Shahwan, T., Sirriah, S.A., Nairat, M., Boyaci, E., Eroglu, A.E., Scott, T.B., Hallam, K.R. 2011. Green synthesis of iron nanoparticles and their application as a Fenton-like catalyst for the degradation of aqueous cationic and anionic dyes. Chemical Engineering Journal, 172: 258-266.

Shankar, S.S., Rai, A., Ankamwar, B., Singh, A., Ahmad, A., Sastry, M. 2004. Biological synthesis of triangular gold nanoprisms. Nature Materials, 3: 482.

Shinde, N.C., Keskar, N.J., Argade, P.D. 2012. Nanoparticles: Advances in drug delivery systems. Research Journal Pharmacy Biological Chemical Science, 3: 922-929.

Shukla, R., Chanda, N., Katti, K.K., Katti, K.V. 2012. Green nanotechnology-a sustainable approach in the nano-revolution. In: Sustainable Preparation of Metal Nanoparticles: Methods and Applications, pp. 144-156.

Singh, M., Manikandan, S., Kumaraguru, A. 2011. Nanoparticles: a new technology with wide applications. Research Journal of Nanoscience and Nanotechnology, 1: 1-11.

Stoimenov, P.K., Klinger, R.L., Marchin, G.L., Klabunde, K.J. 2002. Metal oxide nanoparticles as bactericidal agents. Langmuir, 18: 6679-6686.

Suganya, D., Rajan, M., Ramesh, R. 2016. Green synthesis of iron oxide nanoparticles from leaf extract of Passiflora foetida and its antibacterial activity. International Journal Current Research, 8: 42081-42085.

Tartaj, P., del Puerto Morales, M., VeintemillasVerdaguer, S., González-Carreño, T., Serna, C.J. 2003. The preparation of magnetic nanoparticles for applications in biomedicine. Journal of Physics
D: Applied Physics, 36: R182.

Tartaj, P., González-Carreño, T., Serna, C.J. 2004. From hollow to dense spheres: control of dipolar interactions by tailoring the architecture in colloidal aggregates of super paramagnetic iron oxide nanocrystals. Advanced Materials, 16: 529-533.

Tartaj, P., Morales, M., Gonzalez-Carreno, T., Veintemillas-Verdaguer, S., Serna, C. 2005. Advances in magnetic nanoparticles for biotechnology applications. Journal of Magnetism and Magnetic Materials, 290: 28-34.

Thakkar, K.N., Mhatre, S.S., Parikh, R.Y. 2010. Biological synthesis of metallic nanoparticles. Nanomedicine: Nanotechnology, Biology and Medicine, 6: 257-262.

Vidal-Vidal, J., Rivas, J., López-Quintela, M. 2006. Synthesis of monodisperse maghemite nanoparticles by the micro-emulsion method. Colloids and Surfaces A: Physicochemical and Engineering Aspects, 288: 44-51.

Vijayakumar, R., Koltypin, Y., Felner, I., Gedanken, A. 2000. Sonochemical synthesis and characterization of pure nanometer-sized $\mathrm{Fe}_{3} \mathrm{O}_{4}$ particles. Materials Science and Engineering: A, 286: 101-105.

Vimbela, G.V., Ngo, S.M., Fraze, C., Yang, L., Stout, D.A. 2017. Antibacterial properties and toxicity from metallic nanomaterials. International Journal of Nanomedicine, 12: 3941.

Walsch, J., Dultz, S. 2010. Effects of pH, Ca-and SO 4-concentration on surface charge and colloidal stability of goethite and hematite-consequences for the adsorption of anionic organic substances. Clay Minerals, 45: 1-13.

Wu, W., He, Q., Jiang, C. 2008. Magnetic iron oxide nanoparticles: synthesis and surface functionalization strategies. Nanoscale Research Letters, 3: 397.

Xu, Z.P., Zeng, Q.H., Lu, G.Q., Yu, A.B. 2006. Inorganic nanoparticles as carriers for efficient cellular delivery. Chemical Engineering Science, 61: 10271040.

Zhang, G.-Y., Feng, Y., Xu, Y.-Y., Gao, D.-Z., Sun, Y.Q. 2012. Controlled synthesis of mesoporous $\alpha$ $\mathrm{Fe}_{2} \mathrm{O}_{3}$ nanorods and visible light photocatalytic property. Materials Research Bulletin, 47: 625-630.

Zhou, Y., Kong, Y., Kundu, S., Cirillo, J.D., Liang, H. 2012. Antibacterial activities of gold and silver nanoparticles against Escherichia coli and Bacillus calmette-guérin. Journal of Nanobiotechnology, 10: 19 . 